Revue

Revue de l'histoire des religions

del'histoire des religions

\title{
"The Father and his Eldest Son". The Depiction of the 1667 Muscovite Palm Sunday Procession by the Metropolitan of Gaza Paisios Ligaridis and its
} Significance

"Le Père et son Fils Ainé ": la description de la fête des Rameaux célébrée à Moscou en 1667, faite par le Métropolite de Gaza Paisios Ligaridis, et sa signification

Ovidiu Olar

\section{(2) OpenEdition}

\section{Electronic version}

URL: http://journals.openedition.org/rhr/8841

DOI: $10.4000 /$ rhr.8841

ISSN: 2105-2573

\section{Publisher}

Armand Colin

Printed version

Date of publication: 1 March 2018

Number of pages: 5-36

ISBN: 978-2-200-93166-7

ISSN: 0035-1423

\section{Electronic reference}

Ovidiu Olar, "'The Father and his Eldest Son". The Depiction of the 1667 Muscovite Palm Sunday Procession by the Metropolitan of Gaza Paisios Ligaridis and its Significance", Revue de l'histoire des religions [Online], 1 | 2018, Online since 01 March 2020, connection on 15 January 2021. URL: http:// journals.openedition.org/rhr/8841; DOI: https://doi.org/10.4000/rhr.8841 


\section{"The Father and his Eldest Son" The Depiction of the 1667 Muscovite Palm Sunday Procession by the Metropolitan of Gaza Paisios Ligaridis and its Significance}

First attested in 1558 and abolished by Peter the Great in 1697, the Muscovite Palm Sunday ritual has attracted the attention of many scholars. Due to Michael S. Flier's insightful semiotic analysis, the role played by Patriarch Nikon in the refashioning of this ritual is also well known. Nevertheless, a very interesting depiction of the 1667 Palm Sunday ritual still awaits proper analysis. Included by the Metropolitan of Gaza Paisios Ligaridis in his famous and controversial History of the 1666-1667 Council that deposed Nikon, this depiction of the ritual allows us to understand better the roles ascribed to Nikon's successor, Patriarch Joseph, and to Tsar Aleksei Mikhailovich. The aim of this study is to put Ligaridis' description of the 1667 Palm Sunday procession in context and to see how the results fit into the framework of previous researches.

\section{«Le Père et son Fils Ainé » : la description de la fête des Rameaux célébrée à Moscou en 1667, faite par le Métropolite de Gaza Paisios Ligaridis, et sa signification}

Attestée pour la première fois en 1667 et « abolie » par Pierre le Grand en 1697, la célébration moscovite du dimanche des Rameaux à fait couler beaucoup d'encre. Grâce à l'analyse sémiotique dense de Michael S. Flier, le rôle joué par le patriarche Nikon dans la réformation dudit rituel est également connu. Néanmoins, une description particulièrement intéressante de la fête des Rameaux de 1667 attend toujours une étude approfondie. Incluse par le métropolite de Gaza Paisios Ligaridis dans sa fameuse et controversée Histoire du concile de 1666-1667 qui a déposé Nikon, cette description nous permet de comprendre mieux le rôle attribué au successeur de celui-ci, le patriarche Joseph, et au tsar Aleksei Mikhailovich. Le but de cette étude est de placer dans son contexte le récit de Ligaridis et de voir comment s'insèrent les résultats dans le cadre des recherches antérieures. 
"What the fox cannot get, it turns into vegetables hanging from the rafters". ${ }^{1}$

First described in 1558 by an English merchant belonging to the party of Anthony Jenkinson and "abolished" by Tsar Peter the Great in 1697, the Muscovite Palm Sunday ritual has attracted the attention of many scholars. ${ }^{2}$ Thanks to Michael S. Flier's insightful semiotic analysis, the role played by Patriarch Nikon in

* This work was supported by a grant from the Romanian National Authority for Scientific Research and Innovation (CNCS - UEFISCDI), project number PN-II-RU-TE-2014-4-2162.

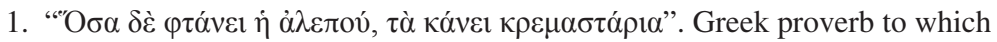
Paisios Ligaridis alludes in a 1662 letter to boyar Simeon Lukjanovich Streshnev. See Ihor Ševčenko, "A New Greek Source for the Nikon Affair: Sixty-One Answers Given by Paisios Ligarides to Tsar Aleksej Mixajlovič”, Palceoslavica 7 (1999), p. 65-83 (73, 78).

2. See, for example, Michael S. Flyer, "The Iconography of Royal Procession: Ivan the Terrible and the Muscovite Palm Sunday Ritual", in Heinz Duchhardt, Richard A. Jackson, David Sturdy (ed.), European Monarchy. Its Evolution and Practice from Roman Antiquity to Modern Times, Stuttgart: Franz Steiner 1992, p. 109-125; Idem, "Breaking the Code: The Image of the Tsar in the Muscovite Palm Sunday Ritual", in Idem, Daniel Rowland (ed.), Medieval Russian Culture II, Berkeley \& Los Angeles: University of California Press 1994, p. 213-242; Andrei V. Korenevskij, "Officium stratoris и «шествие на осляти»: к вопросу о сопоставимости религиозно-политических доктрин западноевропейского и русского Средневековья" [Officium Stratoris and "Procession on the Ass": The Question of Compatibility of West-European and Russian Medieval Religious and Political Doctrines], Ab Imperio 1 (2002), p. 185-204; Michael S. Flyer, "Political Ideas and Ritual," in Maureen Perrie (ed.), Cambridge History of Russia I. From Early Rus' to 1689, Cambridge: Cambridge University Press 2006, p. 387-408; Evgenij V. Pchelov, “«Чудо-дерево» Московского царства: верба в церемонии шествия на осляти в XVI - XVII вв." ["Miracle-Tree" of Muscovite Tsardom: The Pussy Willow in the Procession on the Ass in the $16^{\text {th }}-17^{\text {th }}$ Centuries], Традиционная культура [Traditional Culture] 4 (2010), p. 109-114; Michael S. Flyer, "Образ государя в московском обряде Вербного воскресенья" [The Image of the Tsar in the Muscovite Palm Sunday Ritual], in Alexei M. Lidov (ed.), Пространственные иконы. Перформативное в Византии и Древней $P$ Рси [Spatial icons. Performativity in Byzantium and Medieval Russia], Moscow: Индрик 2011, p. 533-562; Natalia I. Sazonova," «Шествие на осляти» в России XVI-XVII вв.: содержание и смысловые трансформации" [The "Procession on the Ass" in Russia in the $16^{\text {th }}-17^{\text {th }}$ Centuries: Content and Semantic Transformation], ПРАЕHMA 2(4) (2015), p. 115-125. See also Nancy Shields Kollmann, "Muscovite Political Culture", in Abbott Gleason (ed.), A Companion to Russian History, Chichester: Wiley-Blackwell 2009, p. 89-104. 
the refashioning of this ritual - by far "the most impressive of all the royal rituals in Moscow" - is also well known. ${ }^{3}$ Nevertheless, a rather peculiar depiction of the 1667 Palm Sunday celebrations still awaits proper scrutiny and debate. Included by the Metropolitan of Gaza Paisios Ligaridis in his famous and controversial Report on the 1666-1667 Council that deposed and condemned Nikon, this depiction allows us to understand better the roles ascribed during the ritual to Nikon's successor, Patriarch Joasaph II, and to Tsar Aleksey Mikhailovich. The aim of the present paper is to put Ligaridis' description of the 1667 procession in context and to see how the results fit into the framework of previous research both on Nikon and on rituals in Early Modern Europe.

In order to do so, the first part will focus on the portrayal of the event in the 1667 Report, or Account, of the partial council which took place in illustrious Moscow against the erstwhile Patriarch Nikon. ${ }^{4}$ The second part will try to identify the multifold rationales behind Ligaridis' exegesis. A short third part will compare the

3. Michael S. Flyer, "Court Ceremony in an Age of Reform: Patriarch Nikon and the Palm Sunday Ritual", in Samuel H. Baron, Nancy Shields Kollmann (ed.), Religion and Culture in Early Modern Russia and Ukraine, DeKalb (Il.): Northern Illinois University Press 1997, p. 73-95.

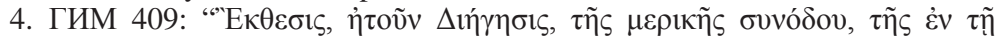

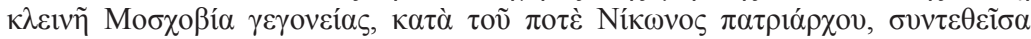

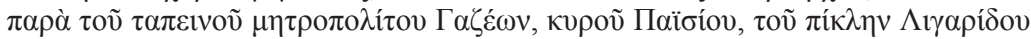

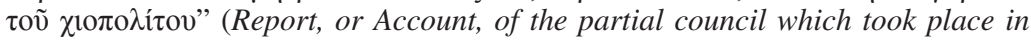
illustrious Moscow against the erstwhile Patriarch Nikon, composed by the humble Metropolitan of Gaza, kyr Paisios Ligaridis of Chios). Unfortunately, the Greek text has not been published yet; here, I will use the English translation provided by William Palmer, The Patriarch and the Tsar III. History of the Condemnation of the Patriarch Nicon by a Plenary Council of the Orthodox Catholic Eastern Church, Held at Moscow A.D. 1666-1667: Written by Paisius Ligarides of Scio..., London: Trübner 1873, p. 300-303. For ГИМ 409, see Boris L. Fonkič, "Греческое книгописание в России в XVII в." (Greek Book-Writing in Russia in the $17^{\text {th }}$ Century), in Dmitrij S. Likhačev (ed.), Книжные центры Древней Руси. XVII век. Разные аспекты исследования (Scribal Centres of Ancient Russia. Different Aspects of the Research), St Petersburg: Наука 1994, p. 18-63 (44) [= Boris L. Fonkič, Греческие рукописи и документы в России в XIV-начале $X V I I I$ 8. (Greek Manuscripts and Documents in Russia in the $14^{\text {th }}-$ beginning of the $18^{\text {th }}$ Centuries), Moscow: Индрик 2003]; Idem (ed.), Греческие документы и рукописи, иконы и памятники прикладного искусства московских собраний. Каталог высттавки (Greek Documents and Manuscripts, Icons and Applied Art Objects from Moscow Repositories), Moscow: Индрик 1995. For a $18^{\text {th }}$ century version, see BAR ms. gr. 675 (Constantin Litzica, BAR. Catalogul manuscriptelor grecești [BAR Catalogue of the Greek Manuscripts], Bucharest: Institutul de Arte Grafice "Carol Göbl” 1909, p. 196). 
1667 Muscovite Palm Sunday ritual with a 1658 Wallachian Palm Sunday ritual described by Archdeacon Būluṣ, the son of Patriarch Makāriyūs Ibn al-Za'īm of Antioch - a ritual in which Ligaridis might also have taken part. ${ }^{5}$ Based on this evidence, it will be finally argued that the 1667 re-enactment of Christ's entry into Jerusalem was indeed intended to strengthen the Tsar's authority, to emphasize the sacred character of his power, and to show that the conflict opposing State and Church was over. Still, both as a participant, in his capacity of Metropolitan of Gaza, and as a narrator, as the author of the Report, Ligaridis chose to stress in his account all these aspects by turning Nikon's arguments against him: in 1667, all changes introduced by the deposed Patriarch during his tenure with regards to the Palm Sunday ritual were discarded.

\section{Moscow I667}

According to Ligaridis, the Palm Sunday of 1667 "was observed with great pomp". Patriarch Joasaph rode on a white horse. Dressed in imperial robes, the Tsar led the way, holding the mount's rein. Vested in their official attire and carrying their pastoral staffs, preceded by the cross, followed by the imperial standard, and accompanied by singers singing the troparion of the day, all Bishops and Metropolitans moved slowly from Dormition Cathedral towards "the handsome convent of the Trinity", that is the church of the Intercession of the Most Holy Mother of God on the Moat. ${ }^{6}$ Once arrived there, the Patriarch and the Tsar put on "more festal robes". Those of the sovereign were magnificent, underlines Ligaridis, as they included a pearl diadem, emerald

5. Mrs Ioana Feodorov is preparing a bilingual Arabic-English edition of the Travels of Patriarch Makāriyūs written by Būluṣ. Here, I will use the English translation provided in her "Mihnea III Radu, Prince of Wallachia, as seen by Paul of Aleppo and his Father Makāriyūs ibn al-Za'īm, Patriarch of Antioch", RESEE 52 (2014), 1-4, p. 289-306 (296-297). See also Paul din Alep - Jurnal de călătorie în Moldova și Valahia [Paul of Aleppo - Travel Journal in Moldavia and Wallachia] (ed. Ioana Feodorov), Bucharest / Brăila: Editura Academiei Române - Istros 2014, p. 411-412.

6. On this church, commonly known as the church of Basil the Blessed in Red Square, see Michael S. Flier, "Filling in the Blanks: The Church of the Intercession and the Architectonics of Medieval Muscovite Ritual", HUS 19 (1995), p. 120-137. 
pectorals and a fragment of the True Cross. "It was indeed a sight to astonish the whole city".

Then the litany was sung. And when it was about time to read the passage from the Gospel according to Matthew in which Jesus, who is preparing to enter Jerusalem, sends two disciples to bring Him an ass and a colt (Matthew 21: 2), two priests brought a horse covered in white linen. The Patriarch mounted it and went blessing, holding the cross in his right hand and the Gospels close to his chest. The Bishops and the Metropolitans followed, while the singing boys sang cheerfully around a tree adorned with "apples filled with all manner of sweets" and other similar "fruits".

Back at Dormition Cathedral, on a road paved with carpets and studded with coloured bits of cloth, the two Eastern Patriarchs present in Moscow, Paisios of Jerusalem and Makāriyūs of Antioch, joined in for the celebration of the liturgy. In an impressive display of light and sound, the antiphons were sung by two alternate choirs, the Gospel was read both in Greek and Slavonic, and all three Patriarchs loudly wished the "heavencrowned Emperor" of All Rus', his "most religious Augusta" and their children to be long remembered by God. Once the office was over, Patriarch Joasaph blessed the fruit-tree and distributed its branches to the faithful. A feast was organized in the patriarchal palace, lavish dishes being sent to the Tsar, absent on account of fatigue.

Ligaridis has no doubts whatsoever with regards to the significance of this "spiritual ride and public procession": it is a re-enactment of Christ's entry into Jerusalem and, on a higher allegorical level, a prefiguration of Christ's Second Coming. The troparion and the evangelic passages used during the ritual are very clear; in addition, the liturgical exegesis of Germanos of Constantinople and of Symeon of Thessalonica are cited in support of this (double) interpretation.

Ligaridis also seems keen to show that the Muscovite ritual was ancient and deeply rooted in the Eastern tradition. On one hand, he quotes Basil of Caesarea, Epiphanios of Salamis, Socrates the Scholastic, Theodoret of Cyrus, Theophylaktos and Kedrenos in an attempt to underline the ancient character of the troparion, of the antiphonal singing, and of the Cherubic 
Hymn. On the other hand, he states that the origins of the equerry service performed by the Tsar to the Patriarch go a long way back, as the officium stratoris would have been provided by Alexander the Great to the high priest of the Jews, Jaddua, by Constantine the Great to Pope Sylvester, and by Justinian to Pope Agatho.

Nevertheless, all three episodes invoked by Ligaridis with respect to the equerry service are very contentious. The encounter between Alexander the Great and Jaddua is recorded in Flavius Josephus' Jewish Antiquities. Yet the horse and the rein are missing: the historian says only that the Emperor prostrated himself before the High Priest, dressed in priestly garments, and that he "gave [him] his hand" and "entered" Jerusalem. Another (minor) detail is that, in the Antiquities, the Macedonian general scandalized by Alexander's behaviour is Parmenion, and not Hephaistion Amyntoros, as Ligaridis recounts. ${ }^{7}$ Was the Metropolitan of Gaza erroneously quoting from memory, in a hurry or for lack of a good library? ${ }^{8}$ Or did he misquote on purpose? If so, what might this purpose have been?

With the second episode things get even more intricate. The encounter between Constantine the Great and Sylvester is recorded in an alleged imperial decree called Constitutum Constantini, which enshrines a "Donation" purportedly made by the Emperor to the Pope. The horse and the rein are present and Constantine acts as a groom to Sylvester, yet the document had been long proven to

7. Josephus, Jewish Antiquities IX-XI (ed. Ralph Marcus), London / Cambridge, Mass.: William Heinemann / Harvard University Press 1958, p. 472-479 (11: 329-339).

8. In September 1664, Ligaridis complained to Lazar Baranovyč that Patriarch Nikon had transformed the Tsar's library into "a closed garden and a sealed well" and restricted access to the manuscripts brought from Athos by Arsenij Sukhanov. Around 1665-1666, according to Simjaon Polacki, Ligaridis refused to engage in a polemic with the Roman-Catholic theologian Mikołaj Cichowski for the lack of a good library. See Peter A. Rolland, "Correspondence between Two Capitals: Simjaon Polacki's Letters to Varlaam Jasyns'kyj (1664-1670)", HUS17 (1993), 3-4, p. 341-352 (346-347). Ligaridis had probably other reasons for not getting involved in the polemic, but his Muscovite library might have been lacking indeed. On this library, see Ernst Chr. Suttner, "Panteleimon (Paisios) Ligarides und Nicolae Milescu. Ein Beitrag zur Frage nach der Offenheit des walachischen Fürstentums für das Bildungsgut der Zeit im 2. Drittel des 17. Jahrhunderts", Kirche im Osten 26 (1983), p. 73-94. 
be a forgery. ${ }^{9}$ Was Ligaridis unaware of the fact? Or did he ignore it on purpose? Again, for what purpose?

As for the third and last episode, the performance of the officium stratoris by Justinian to Pope Agatho is not recorded by any contemporary writer. Was Ligaridis referring to a text that has so far escaped scholarly attention? Or did he concoct a reference on purpose? If so, to what end?

In my opinion, there was a purpose, and this purpose results clearly from the text: praising the "most potent" Tsar. Aleksei Mikhailovich is placed in the same category as Alexander the Great, Constantine the Great and Justinian, also the Great. Bishops and Metropolitans bow before him at the beginning of the ceremony. His standard - possibly the double-headed crowned eagle that appears wonderfully in the abyss of the 1663 monumental Muscovite Bible ${ }^{10}$ - closely follows the processional cross. He wears on his breast a fragment of the True Cross. He plays an important role both in the re-enactment of Jesus' progress from Bethany to Jerusalem and in the prefiguration of Christ's Second Coming - a crucial element, given that many Muscovites strongly believed the Apocalypse and the Last Judgement to be imminent. ${ }^{11} \mathrm{He}$ is extolled during the Holy Liturgy. As "the eldest son" of the Patriarch, he acts as a groom for Joasaph, but he does it only in order to honour God. As Alexander the Great explained to Parmenion, "It was not before him that I prostrated myself but the God of whom he has the honour to be high priest". ${ }^{12}$ Acting like this, the Tsar shows that he is the true defender of the Church; to quote Ligaridis, "And now our Emperor led by the rein not

9. For the Latin text, see Horst Fuhrmann, Das Constitutum Constantini (Konstantinische Schenkung), Hannover: Hahnsche Buchhandlung 1968. For an English translation, see Johannes Fried, «Donation of Constantine» and "Constitutum Constantini". The Misinterpretation of a Fiction and its Original Meaning (With a Contribution by Wolfram Brandes The Satraps of Constantine), Berlin-New York: Walter de Gruyter 2007.

10. Simon Franklin, "Printing Moscow: Significances of the Frontispiece to the 1663 Bible", SEER 88 (2010), 1-2, p. 73-95 (82-83).

11. For details, see Tatiana A. Oparina, "Число 1666 в русской книжности середины-третьей четверти XVII в.” [Number 1666 in Russian Book-learning in the Middle-Third Quarter of the $17^{\text {th }} \mathrm{C}$.], in Marina S. Kiseleva (ed.), Человек между Царством и Империей [Man between Tsardom and Empire], Moscow: Институт человека РАН 2003, p. 287-318; Maureen Perrie, "Moscow in 1666: New Jerusalem, Third Rome, Third Apostasy", Qucestio Rossica 3 (2014), p. 75-85.

12. Josephus, Jewish Antiquities..., p. 472-479 (11: 329-339). 
so much that horse on which Kyr Joasaph rode as the LutheroCalvinists, who set at naught the priesthood". ${ }^{13}$

Yet there are signs of a second purpose. The flawed quotes, the mention of the relic of the True Cross, the downplaying of the Patriarch's role and especially the interpretation given to the "Donation of Constantine" and to the equerry service - all suggest a dispute with former Patriarch Nikon.

Nikon had also shown a pronounced interest in the cult of the True Cross. ${ }^{14} \mathrm{He}$ had given a completely different interpretation to the "Donation of Constantine", which he held in high respect, and to the officium stratoris, and he had in fact refuted Ligaridis' opinion on the topic, just a couple of years earlier. As has been briefly stated and as we shall see further on, he had even radically revised the Palm Sunday ritual: unlike the 1655 ceremony depicted by Būluṣ of Aleppo in the Travels of Patriarch Makāriyūs, the one described by the book of patriarchal appearances under the year 1656 strives for "greater likeness" with the event commemorated. However, the 1667 ritual, as described by Ligaridis, closely resembles the ceremony depicted by Būluṣ, and not the one "reformed" by Nikon. ${ }^{15}$

13. William Palmer, The Patriarch and the Tsar III. History..., p. 300.

14. For the "politics of True Cross relics in the Muscovite center", see Isolde Thyrêt, "The Cult of the True Cross in Muscovy and its Reception in the Center and the Regions", Forschungen zur osteuropäischen Geschichte 63 (2004) [Andreas Kappeler (ed.), Die Geschichte Russlands im 16. und 17. Jahrhundert aus der Perspektive seiner Regionen], p. 236-258; Vera G. Tchentsova, Икона Иверской Богоматери. (Очерки истории отношений Греческой иеркви с Россией в середине XVII в. по документам РГАДА) [The Icon of the Mother of God from Iviron. Essay on the Relationship between the Greek Church and Russia in the Middle of the $17^{\text {th }}$ Century, Based on Documents from RGADA], Moscow: Индрик 2010; Eadem, "Писец Николай Армириот и Крест царя Константина: К истории связей Ватопедского монастыря с Россией в XVII веке" [Scribe Nikolai Armiriot and the Cross of Emperor Constantine: On the History of the Contacts between Vatopedi Monastery and Russia in the $17^{\text {th }}$ Century], Palcooslavica 19 (2011), 2, p. 60-109.

15. For the 1655 Palm Sunday ritual, see The Travels of Macarius, Patriarch of Antioch Written by his Attendant Archdeacon Paul of Aleppo, in Arabic (translated by F.C. Belfour) II, London: The Oriental Translation Fund of GreatBritain and Ireland 1836, p. 88-93; "Путешествие антиохийского патриарха Макария в Россию в половине 17 века, описанное его сыном архидиаконом Павлом Алеппским" [The Journey of Patriarch Macarius of Antioch to Russia at the Middle of the $17^{\text {th }}$ Century, Written by his son, Archdeacon Paul of Aleppo] (translated by Georgij А. Murkos), ЧОИДР 1898-3, p. 174-181. On the 1656 Palm Sunday ritual, see Aleksandr Golubtsov (ed.), “Чиновники Московского 
Therefore, in order to grasp the full meaning of Ligaridis' depiction of the 1667 Palm Sunday ceremony, it would be useful to place it in its immediate context - the open conflict opposing Tsar Aleksei Mikhailovich and Patriarch Nikon from 1658 to 1666 - and to analyse the genesis and the role of the Report on the 1666-1667 Council.

\section{Patriarch Versus Tsar}

In July 1658, Patriarch Nikon had left Moscow to retire to the "New Jerusalem" monastery of the Resurrection, his recent foundation on the Istra River. After years of steady collaboration, he had parted ways with the Tsar: their ideas about the relationship between Church and State had grown divergent. ${ }^{16}$

Elected Patriarch of Muscovy and of All Rus' in July 1652, Nikon had given a new impetus to the reform desired by Aleksei Mikhailovich and by the informal group around him, the so-called "Zealots of Piety", a reform that was deemed mandatory for Russia to fulfil its foretold exceptional destiny. Advocating a strict alignment to the principles of the Holy Universal, Apostolic, Oriental and Orthodox Church, as well as a complete rooting out of innovation "from all aspects of Church life", Nikon had embarked on a very ambitious project that aimed to transform Moscow into a "New Jerusalem" and to emphasize the Tsar's role as a "New Constantine". ${ }^{17}$

Успенского собора" [Hierarchical Service Books of the Dormition Cathedral in Moscow], ЧОИДР 1907-3, p. 250-253. See also The Present State of Russia, In a Letter to a Friend at London; Written by an Eminent Person residing at the Great Tzars Court at Mosco for the space of nine years, London: John Winter 1671, p. 16-17; the "eminent person" is Samuel Collins, and he describes (probably) the 1660 Palm Sunday ritual.

16. Since Nikolai F. Kapterev's Патриарх Никон и иарь Алексей Михайлович I-II [Patriarch Nikon and Tsar Aleksei Mikhailovich] (Sergiev Posad: Типография Свято-Троицкой Сергиевой Лавры 1909-1913), the number of studies dedicated to the topic has increased relentlessly. For an outline of the relationship between Nikon and the Tsar, see Wolfram von Scheliha, Russland und die orthodoxe Universalkirche in der Patriarchatsperiode 1589-1721, Wiesbaden: Harrassowitz 2004, p. 260-289.

17. For details, see Paul Meyendorff, Russia, Ritual and Reform. The Liturgical Reforms of Nikon in the $17^{\text {th }}$ Century, Crestwood, NY: St. Vladimir's Seminary Press 1991; Daniel B. Rowland, "Moscow - The Third Rome or the New Israel", 
As Kevin M. Kain has convincingly shown, in the years that followed Nikon's election, sacred objects and relics had been transferred to Moscow, monasteries had been built and richly endowed, the Church books had been corrected, the religious and secular rituals had been reformed, and a "new style", more "Byzantine", of vestments, regalia and icons had been promoted in a huge effort to depict "both Russia's inheritance of the Byzantine legacy and claims to be 'New Jerusalem'". ${ }^{18}$

For example, the 1653 Muscovite edition of the Book of the Pilot (Кормчая книга) included, in addition to the canon-law texts printed three years before, the decisions of the 1593 synod held in Constantinople, which acknowledged the creation of the Moscow Patriarchate, the "Donation" of Constantine, and a short essay on Rome's schism. Their message was clear: because "old" Rome had succumbed to heresy and Constantinople had fallen to the Ottomans, Moscow had inherited their privileges. ${ }^{19}$

Russian Review 55 (1996), 4, p. 591-614; Isolde Thyrêt, "The Cult of the True Cross..."; Vera G. Tchentsova, Икона..., passim; Eadem, "Писец Николай Армириот..."; Eadem, "La croix et la bannière: le monastère de Vatopédi et la formation de l'idéologie constantinienne dans la Moscovie du XVII siècle", in Radu G. Păun (ed.), Histoire, mémoire et dévotion. Regards croisés sur la construction des identités dans le monde orthodoxe aux époques byzantine et postbyzantine, Seyssel: La pomme d'or 2016, p. 91-142; Kevin M. Kain, "Before New Jerusalem: Patriarch Nikon's Iverskii and Krestnyi Monasteries", Russian Review 39 (2012), 1-2, p. 173-271.

18. Ibidem (the quote is at p. 207). See also Idem, "The 'Sacred Waters' of the 'Holy Lake' Valdai: A Wellspring of Hierotopic Activities in the Reign of Tsar Aleksei Mikhailovich", in Alexei Lidov (ed.), Живоносныгй источник. Вода в иеротопии и иконографии христианского мира / The Life-Giving Source. Water in the Hierotopy and Iconography of the Christian World, Moscow: Filigran 2014, p. 152-156.

19. Kevin M. Kain, "Before New Jerusalem...", p. 192-193. For the Acts of the 1593 synod, see Boris L. Fonkič, “Акт Константинопольского собора 1593г. обосновании Московского патриархата" [The Acts of the 1593 Constantinopolitan Synod on the Foundation of the Moscow Patriarchate], Cyrillomethodianum 11 (1987), p. 9-31 [=Idem, Греческие рукописи и документыл.., р. 385-399]; for an English translation, see William Palmer, The Patriarch and the Tsar IV. Services of the Patriarch Nicon to the Church and State of his Country, and their Requital by the Creation of a Merely National or State Church in Russia..., London: Trübner 1876, p. 179-191. For the circulation of the "Donation" of Constantine in Russia before Nikon, see Maria Pliukhanova, "La Donazione di Costantino in Russia tra XV e XVI secolo", in Giorgio Bonamente, Giorgio Cracco, Klaus Rosen(ed.), Costantino il Grande tra medioevo ed età moderna. Atti del convegno (Trento, 22-24 aprile 2004), Bologna: Il Mulino 2008, p. 209-232; Alessandro Maria Bruni, "Tradizioni 
Several "ritualistic re-enactments around the "Cross of Constantine"" - whose relics were brought from the monastery of Vatopedi -, with the Tsar in the role of the successor of the Byzantine emperors, belong to the same scenario, and the same can be said about the adoption of a white cowl for the Patriarch, similar to the one allegedly offered by Constantine the Great to Pope Sylvester. Their message was equally clear: Russia, whose ruler wears a fragment of the True Cross (a present from Nikon), is the "New Holy Land". 20

Yet for the present paper the changes operated in the Palm Sunday ritual matter most. As stated above, we owe to Michael S. Flier a lengthy analysis of the variations introduced in early 1656. According to the American historian, Nikon obtained either from Patriarch Paisios of Jerusalem, or from Archdeacon Arsenij Sukhanov, or from Patriarch Makāriyūs of Antioch a detailed description of the Greek rites performed in Jerusalem on Palm Sunday. Noticing some differences in relation to the Muscovite custom, and preferring a sacramental / commemorative approach to a symbolic / theophanic one, he tried to implement a more accurate ritual from a historical perspective. Such a re-enactment / commemoration of Jesus' Entry into Jerusalem would have been closer to "reality". It would have "enhanced the macro-liturgy in the 'nave' that was Red Square", it would have allowed a better assimilation by the participants of a model centred on the strict

ecclesiastiche, culto e teologie russe. Il Constantinus Orthodoxus in Russia nei secoli X-XV e la ricezione del Constitutum", in Costantino I. Enciclopedia costantiniana sulla figura e l'immagine dell'imperatore del cosiddetto editto di Milano: 313-2013 II, Roma: Istituto italiano dell'Enciclopedia Treccani 2013, p. 487-500. For the inclusion of the "Donation" in Кормчая, see Aleksei S. Pavlov, "Подложная дарственная грамота Константина Великаго папь Сильвестру въ полномъ греческомъ и славянскомъ переводъ” (The False Donation of Constantin the Great to Pope Sylvester in Full Greek and Latin Translation), VV 3 (1896), 1, p. 18-82 (43-44); Ivan Žužek SJ, Kormčaja Kniga. Studies on the Chief Code of Russian Canon Law, Rome: PIOS 1964, p. 54; Francis J. Thomson, "The Intellectual Difference between Muscovy and Ruthenia in the Seventeenth Century. The Case of the Slavonic Translations and the Reception of the Pseudo-Constantinian Constitutum (Donatio Constantini)", Slavica Gandensia 22 (1995), p. 63-107 (70). For the essay, see William Palmer, The Patriarch and the Tsar I. The Replies of the Humble Nicon, by the Mercy of God Patriarch, against the Questions of the Boyar Simeon Streshneff and the Answers of the Metropolitan of Gaza Paisius Ligarides, London: Trübner 1871, p. 662-665.

20. Kevin M. Kain, "Before New Jerusalem...”, p. 211-217. 
imitation of Christ, and it would have better stressed Moscow's prominent status as the New Jerusalem. ${ }^{21}$

In spite of all these, trouble arrived in paradise. In the summer of 1658, Nikon departed from Moscow, and his self-imposed exile created confusion. In March 1659, the Patriarch objected that Metropolitan Pitirim of Krutitsy had replaced him during the Palm Sunday ritual. If the decision were Pitirim's, he wrote, then Pitirim must be excommunicated, for it is not fitting for a mere Metropolitan to re-enact Christ's entry into Jerusalem. If the Tsar were responsible for it, may God forgive him; "but for the future... keep thyself from judging and determining in things which belong not to thee". In reaction, Aleksei Mikhailovich rebuked Nikon for abandoning his flock and reminded him that the Metropolitan of Krutitsy was patriarchal vicar; as such, there was nothing new in Pitirim performing the Palm Sunday ritual in the Patriarch's absence. Nikon retorted that the Metropolitan still needed the consent of the primate, for he alone "is in the figure of Christ". The Tsar's envoys replied that Nikon was not primate anymore; that he had performed the ritual while Metropolitan of Novgorod; and that after becoming Patriarch he had not forbidden the Metropolitans of Novgorod and Kazan to perform it. In response, Nikon invoked ignorance and the lack of time. The talk continued in the same tone, and although it ended with the exiled prelate sending his blessings to the ruler, it was obvious that the situation had reached an impasse: Nikon stated that, although he had not abdicated, he had no intention of returning, therefore the Tsar and the Church should elect a new Patriarch. ${ }^{22}$

The solution proved hard to find, all the more so as Nikon was insisting that he had quit only the office, and not the God-conferred dignity. A council convened in 1660 and decided the Patriarch had indeed abdicated; however, Nikon - who relentlessly contested the legitimacy of this local synod - was not deprived of his priesthood

21. Michael S. Flyer, "Court Ceremony in an Age of Reform...".

22. William Palmer, The Patriarch and the Tsar IV. Services..., p. 164-166 (letter of Nikon to the Tsar), 166-167 (1660 report by Duma courtier Prokofej K. Eleazarov, one of the Tsar's envoys). See Svetlana K. Sevastyanova, Эпистолярное наследие патриарха Никона. Переписка с современниками: исследование и тексты [Epistolary Heritage of Patriarch Nikon: Research and Text], Moscow: Индрик 2007, p. 102 sq. and 596 sq. 
and was allowed to keep his episcopal dignity. To quote Paul Bushkovitch, "the stalemate remained". ${ }^{23}$

But then Ligaridis arrived, "for his own purposes, of his own will", bringing as gifts "a model of the Holy Sepulchre, Jordan water, and Jerusalem candles". ${ }^{24}$ Seizing the opportunity, the Tsar and his proxies received him without delay, while boyar Simeon Lukjanovich Streshnev handed him thirty "delicate" questions concerning the Nikon "affair". ${ }^{25}$ On July $12^{\text {th }} 1662$, Ligaridis wrote to Nikon who, in response to a previous letter, had presented him with his version of the facts and had politely denied him access to his library. "Finding myself to be standing between two parties, I am at a loss to which side to turn", claimed Ligaridis, while manifestly siding with the Tsar. ${ }^{26}$

23. Paul Bushkovitch, Religion and Society in Russia. The Sixteenth and Seventeenth Centuries, New York/Oxford: Oxford University Press 1992, p. 66.

24. In his Report, Ligaridis says he arrived in Moscow "on the $30^{\text {th }}$ day of the pascal festival", and that he met with the Tsar on the $1^{\text {st }}$ of April 1662. Indeed, he was in Putivl on February $12^{\text {th }}$ and in Moscow on March $30^{\text {th }}$; see Liudmila A. Timošina, "Газский митрополит Паисий Лигарид: о некоторых датах и событиях" [The Metropolitan of Gaza Paisios Ligaridis: On Some Dates and Events], КЧ 10 (2012), p. 89-133 (90-102). Ligaridis' “own purpose" included the presentation to the Tsar of letters by Greeks demanding financial aid, as well as the intervention with the authorities on behalf of Greeks needing help, like archbishop Nektarios of Pogoniani; see Nikolai F. Kapterev, Характерь отношеній Росси кь православному Востоку вь XVI и XVII столґтияхь [Character of the Relationships between Russia and the Orthodox East in the $16^{\text {th }}$ and $17^{\text {th }}$ Centuries], Sergiev Posad: M.S. Elov 1914 ${ }^{2}$, p. 190-191; Vera G. Tchentsova, "De Byzance à Moscou par les Pays roumains: un scribe inconnu et le destin d'un manuscrit de l'Acathiste (Mosc. (GIM). Syn. gr. 429 / Vlad. 303) au XVII ${ }^{\mathrm{e}}$ siècle", in Dumitru Țeicu, Ionel Cândea (ed.), Românii în Europa medievală (între Orientul bizantin şi Occidentul latin). Studii în onoarea Profesorului Victor Spinei [The Romanians in Medieval Europe (between the Byzantine East and the Latin West). Studies in Honour of Professor Victor Spinei], Brăila: Istros 2008, p. 429-478 [= "Неизвестный писец греческих грамот 40x-60x гг. XVII (архимандрит Леонтий?) и загадочная судьба рукописи Акафиста (ГИМ. Син. гр. 429 / Влад. 303)", Palceoslavica 16 (2008), 2, p. 22-67].

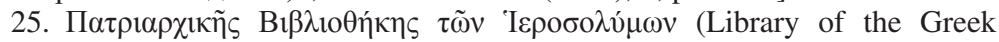
Orthodox Patriarchate in Jerusalem) Hierosolymus gr. 204; Athanasios

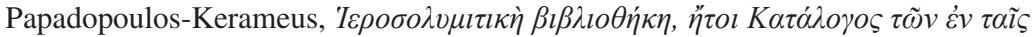

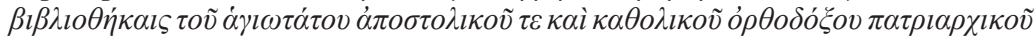

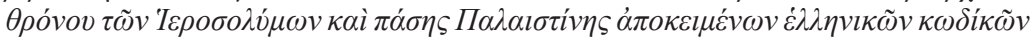
I, St Petersburg: V. Kirschbaum 1891, p. 283-285. See also William Palmer, The Patriarch and the Tsar I. Replies..., p. XXVII-XXXIX; Ihor Ševčenko, "A New Greek...", p. 65-83.

26. William Palmer, The Patriarch and the Tsar III. History..., p. 51-57 (letter of Nikon), 57-69 (letter of Ligaridis). 
Indeed, Ligaridis had quickly chosen to serve Aleksei Mikhailovich; the answers delivered on August $15^{\text {th }} 1662$ to Streshnev prove it, and so do the answers to sixty-one questions received on November $26^{\text {th }} .{ }^{27}$ Nikon had unquestionably abdicated. The Tsar could convene a local synod. This local synod could condemn Nikon. All doubts concerning the ritual had to be solved by recourse to the teachings of the Eastern Church etc. Satisfied, the Tsar and his councillors turned to Ligaridis for advice with respect to Nikon's deposition.

Ligaridis was perfect for the job: the Chios-born scholar was an alumnus of the Greek College of St Athanasius in Rome; he had earned a doctorate in philosophy and theology, with honours; he had spent several years in the capital of the Ottoman empire as a missionary on the payroll of the Congregation de propaganda Fide; he had founded a "Greek and Latin school" in Târgovişte, the main city of Wallachia; baptised according to the "rito greco approbato", he had been ordained a priest by the Uniate Metropolitan of Kiev, Raphael Korsak; he had converted to the Greek rite, he had been ordained Orthodox Metropolitan of Gaza by an old acquaintance of the Muscovite court, Patriarch Paisios of Jerusalem, and he might have pulled the strings of a 1659 Wallachian synod. ${ }^{28}$

27. BAR ms. gr. 490, ff. 25-68; Constantin Litzica, Catalogul..., p. 323-324. The Greek $m s .66$ of the Library of the Parliament of the Hellenes (Bi $\beta \lambda_{10} \theta \eta \dot{\kappa} \kappa \eta$

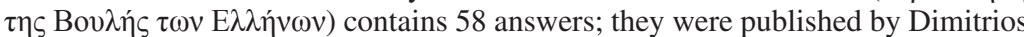

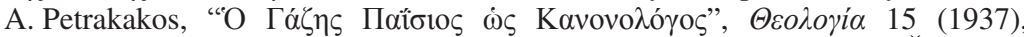
p. 193-207, 289-322. The Sinaiticus $g r$. 1915, ff. 29-60r analysed by Ihor Ševčenko (“A New Greek Source...") also contains 58 answers.

28. See Nikolai I. Subbotin (ed.), Матеріалы для исторіи раскола за первое время его существованія IX/1. Полемическія противь раскола сочиненія православныхь. Паисія Лигарида Опроверженіе челобитной попа Никиты [Materials for the History of Raskol in the First Period of its Existence IX/1. Polemical Orthodox Works against the Raskol. Refutation of the Petition of Priest Nikita by Paisios Ligaridis], Moscow: Братство святаго Петра Митрополита 1895; Émile Legrand, Bibliographie hellénique ou description raisonnée des ouvrages publiés par des Grecs au dix-septième siècle IV, Paris: Alphonse Picard \& Fils 1896, p. 8-61; Nikolai F. Kapterev, Характерь..., p. 182-208;

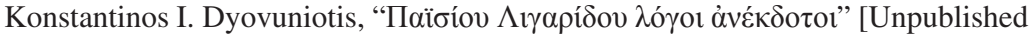
Sermons of Paisios Ligaridis], N $\Sigma 17$ (1922), p. 374-388; George Călinescu, "Altre notizie sui missionari cattolici nei Paesi Romeni", Diplomatarium Italicum 2 (1930), p. 362-363, 378-379, 395-396, 400-401, 404, 430-431; Francisc Pall, "Les relations de Basile Lupu avec l'Orient orthodoxe et particulièrement avec le Patriarcat de Constantinople envisagées surtout d'après les lettres de Ligaridis", 
In addition, news had long reached Moscow about Ligaridis siding with the warden of Epiphany (Bogoiavlenskij) Monastery, Arsenij Sukhanov, during the theological debates conducted in May and June 1650 in the residence of Metropolitan Stephen of Wallachia. ${ }^{29}$ Sukhanov had also described in his secret reports Ligaridis' tonsure as a monk in November 1651 in Jerusalem. ${ }^{30}$ And the Metropolitan of Gaza had dedicated to the Tsar a Book

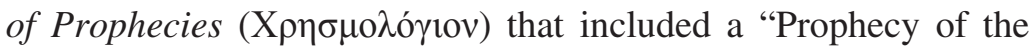
Fair-Haired People" foretelling the liberation of Constantinople from Turkish rule by Russia and temporarily ascribed to Moscow the role of a third Rome. "We, the Romans, handed on to the Muscovites not only our faith, but also the Empire", had written Ligaridis. ${ }^{31}$

Balcania 8 (1945), p. 66-140; Cyril Mango (ed.), The Homilies of Photius, Patriach of Constantinople, Cambridge: Harvard University Press 1958, p. 12-17; Victor Papacostea, "Originile învățământului superior în Țara Românească", Studii 14 (1961), 5, p. 1139-1167 [= "Les origines de l'enseignement supérieur en Valachie", RESEE 1 (1963), 1-2, p. 7-39]; Andreas Septyckyi (ed.), Monumenta Ucraince Historica III. (1650-1670), Rome 1966, p. 299 (n 168); Harry T. Hionides, Paisius Ligarides, New York: Twayne Publishers 1972; Zacharias N. Tsirpanlis,

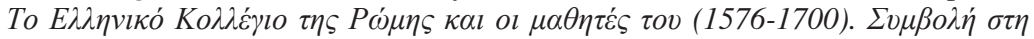

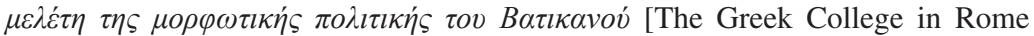
and its Students (1576-1700). A Study of Vatican Cultural Policy], Thessaloniki:

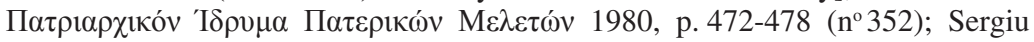
Iosipescu, "Paisie Ligaridi şi studiile clasice în Țara Românească în secolul XVII" [Paisios Ligaridis and the Classical Studies in $17^{\text {th }}$ Century Wallachia], AIIAI 21 (1984), p. 379-385; Gerhard Podskalsky, Griechische Theologie in der Zeit der Türkenherrschaft (1453-1821). Die Orthodoxie im Spannungsfeld der nachreformatorischen Konfessionen des Westens, München: C.H. Beck 1988, p. 251-258; Philip Longworth, "The Strange Career of Paisios Ligarides", History Today 45 (1995), 6, p. 39-45.

29. Arsenij Sukhanov, "Пренія сь греками о вьрь" [Quarrel with the Greeks about the Faith], in Serghei A. Belokurov, "Арсений Сухановь II/1. Сочиненія Арсенія Суханова"'Arsenij Sukhanov II/1. Works of Arsenij Sukhanov], ЧОИДР 1894-4, p. 25-101 (42-43).

30. William Palmer, The Patriarch and the Tsar III. History..., p. 5-6. $C f$. also "Проскинитарий Арсения Суханова 1649-1653 гг." [The Proskinitarij of Arsenij Sukhanov 1649-1653] (ed. Nikolai I. Ivanovskij), Православный Палестинский сборникь [The Orthodox Palestinian Anthology] 7 (1889), 3 (21), p. 1-390.

31. Hierosolymitanus gr. 160 (Athanasios Papadopoulos-Kerameus,

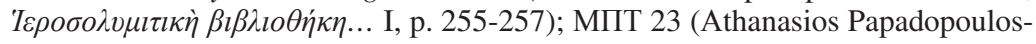

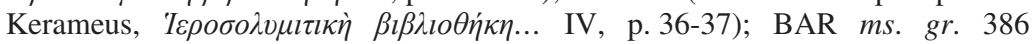
(Constantin Litzica, Catalogul..., p. 6). For details, see Demostene Russo, Studii și critice [Studies and Critiques], Bucharest: Institutul de Arte Grafice "Carol

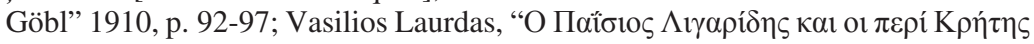


The "former Vatican agent wearing the robes of an Orthodox Metropolitan" was thus asked to find a solution to the Nikon "problem", euphemistically labelled "the widowhood of the Church". ${ }^{32}$ In response, Ligaridis unveiled his master-plan: the Tsar

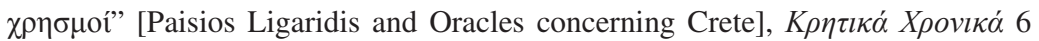
(1952), p. 204-210; Harry T. Hionides, Paisius Ligarides, p. 121-140; Tudor Teoteoi, "L’Europe confessionnelle dans l'Oracle inédit de Païsios Ligaridis", Nouvelle Études d'Histoire 10 (2000), p. 91-96; Idem, "La tradition byzantine de l'oracle inédit de Païsios Ligaridis", RESEE 39 (2001), p. 19-27; Ovidiu Olar, "Profeţie şi istorie. Note asupra câtorva manuscrise călătoare prin Ţările Române (Matei al Mirelor şi Paisie Ligaridi)" / "Prophesy and History. Notes on Manuscripts in Circulation in the Romanian Principalities (Matthew of Myra and Paisios Ligaridis)", in Manuscrise bizantine in colecţii bucureştene / Byzantine Manuscripts in Bucharest's Collections, Bucharest: ICR 2009, p. 35-46, 85-95; Džamilia N. Ramazanova, "Бухарестский список «Хрисмологиона» Паисия Лигарида: палеографическое и кодикологическое исследование" [The Bucharest Manuscript of Paisius Ligaridis' "Chrismologion": Codicological and Palæographical Study], Вестник РГГУ - Исторические науки [RGGU Bulletin - Historical Sciences] 7 (50) / 10 (2010), p. 178-191. For the Russian echo of the "Book of Prophecies", see Nadežda P. Česnokova, Христианский Восток и Россия. Политическое и культурное взаимодействие в середине XVII века (По документам Российского государственного архива древних актов) [The Christian East and Russia. Political and Cultural Intercommunication in the Middle

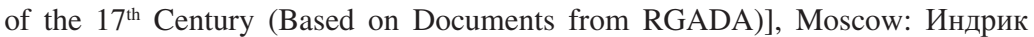
2011, p. 173-175; Eadem, "Русская и греческая традиции Хрисмологиона в России XVII в." [The Russian and Greek Tradition of the Chrismologion in $17^{\text {th }}$-Century Russia], KЧ 13 (2015), p. 126-158. For a different opinion, see Vera G. Tchentsova, "L'eschatologie byzantine dans la pensée historique à la cour d'Alexis Romanov: Paisios Ligaridès, Nicolas le Spathaire et Francesco Barozzi”, in Pierre Gonneau, Ecatherina Rai (ed.), Écrire et réécrire l'histoire russe d'Ivan le Terrible à Vasilij Ključevskij (1547-1917), Paris: Institut d'Études slaves 2013, p. 41-51 [= "Паисий Лигарид, Николай Спафарий и Франческо Бароцци: эсхатологические идеи при дворе царя Алексея Михайловича", in Древняя Русь. Вопросы Медиевистики [Ancient Rus'. Medieval Studies] 1 (55) (2014), p. 69-82]; Eadem, "Les artisans grecs des projets culturels du Patriarche Macaire III d'Antioche", RESEE 52 (2014), p. 315-346.

32. As an anonymous reviewer kindly pointed out, the term was already used for the vacancy on the metropolitan throne of the Russian Church after Isidorus failed to impose the Union of Florence and before Vasilij II organized the election of Jonah, the first autocephalous Metropolitan of Rus'. On the first quote, see James H. Billington, The Icon and the Axe. An Interpretive History of Russian Culture, New York: Alfred A. Knopf 1966, p. 155. On the second one, see William Palmer, The Patriarch and the Tsar III. History..., p. 74. For the role played by Ligaridis in the "Nikon affair", in addition to the studies cited above, see the documents published by Nikolai A. Gibbenet, Историческое иссльдованіе дъла патріарха Никона I-II [A Historical Study of Patriarch Nikon's Case], St Petersburg: Типография Министерства Внутренних Дел 1882-1884. See also Charalambos K. Papastathis, "Païsios Ligaridis et la formation des relations entre l'Église et l'État en Russie au XvII siècle", Cyrillomethodianum 2 (1972-1973), p. 77-85. 
was to appeal to the four Eastern Patriarchs, whose authority was undisputed. Persuaded - the idea had been timidly formulated before, but now it was also advocated by many other Greek ecclesiastics present in Moscow, such as the Archimandrite Dionysios of the monastery of Iviron ${ }^{33}-$, Aleksei Mikhailovich agreed to send to Constantinople Hierodeacon Meletios, "a countryman and friend" of Ligaridis, with oral messages and a set of twenty-five questions, crafted by the Metropolitan of Gaza himself, for the Patriarchs Dionysios of Constantinople, Nektarios of Jerusalem, Paisios of Alexandria and Makāriyūs of Antioch. ${ }^{34}$

In the meantime, Nikon reacted. Having obtained a copy of Ligaridis' answers to the thirty questions of Simeon L. Streshnev, he wrote a lengthy Refutation or Demolishment in which he argued in favour of the separation between the spiritual and the lay realm, voicing also the superiority of the Church over the State. ${ }^{35}$

\section{Patriarch versus Metropolitan}

One of the chapters deals briefly but unfailingly with the Palm Sunday ritual. Streshnev had asked Ligaridis to comment upon the fact that the Tsar granted Nikon all the privileges once granted by Emperor Constantine the Great to Pope Sylvester, that is, full

33. William Palmer, The Patriarch and the Tsar III. History..., p. 75-76.

34. On the text, see ibidem, p. 317-349; regarding the manuscript copies sent from the East and their translation, now in RGADA (ф. 135, одт. III, рубрика $\left.1, \mathrm{n}^{\circ} 7-8\right)$, see Boris L. Fonkič, “Сильвестр Медведев и «Дело патриарха Никона» [Silvestr Medvedev and the "Case of Patriarch Nikon"], ТОДРЛ 50 (1996), p. 624-626. On Meletios, see Boris L. Fonkič, "Мелетий Грек" [Meletios the Greek], in Россия и Христианский Восток I [Russia and the Christian East], Moscow: Индрик 1997, p. 159-178; Andrei K. Stankovič, Boris L. Fonkič, "Печать Мелетия Грека" [The Seal of Meletios the Greek], in Россия и Христианский Восток [Russia and the Christian East] II-III, Moscow: Индрик 2004, p. 412-417; Marina Kurysheva, "Impressions of Seventeenth-Century Seals in Greek Manuscripts Collected in the State Historical Museum of Moscow", in Hlin Ivakin, Nikita Khrapunov, Werner Seibt (ed.), Byzantine and Rus' Seals: Proceedings of the International Colloquium on Rus'-Byzantine Sigillography, Kyiv, Ukraine, 13-16 September 2013, Kiev: The Sheremetiev's Museum 2015, p. 281-328.

35. On the "Возражение или разорение", see Valerie A. Tumins, George Vernadsky (ed.), Patriarch Nikon on Church and State: Nikon's "Refutation", Berlin-New York-Amsterdam: Mouton 1982. For an English translation, see William Palmer, The Patriarch and the Tsar I. The Replies... 
control over all ecclesiastical affairs. (Inevitably, anticipating the answer, the next question was whether the Tsar had the power to withdraw the privileges he himself had granted.) Ligaridis had replied that the almighty Tsar could freely choose whom to honour and whom not to honour. Constantine chose to hold bridle of the horse on which Sylvester sat; so did Justinian to Pope Agapetus, and so did the Russian Tsars on Palm Sunday; King Ahasuerus also decided that Mordecai, a main character of the biblical Book of Esther, and not Haman, would be dressed in royal garments and paraded on a horse by his chief minister. Nonetheless, humility was required from the recipients of such honours, Ligaridis added. Nikon had not used the gifts he had received with humility; he admired himself in them as in a mirror, thus sharing the fate of Narcissus, smitten to death with his own reflection. Therefore, according to the Metropolitan of Gaza, the performance of the officium stratoris on Palm Sunday was a gift accorded by the Tsar, as a sign of respect and by his own will, to the Patriarch. ${ }^{36}$

To all these, Nikon responds bluntly in his Refutation. First of all, Streshnev's allegation that the Tsar chose to hand over to the Patriarch the supervision of all ecclesiastical affairs is "simply a foul blasphemy, and one that exceeds the pride of Lucifer". For the "highest authority of priesthood is not received from kings and emperors": it is the ruler who is anointed by the high priest, as "priesthood is a very much greater thing than royalty". Aleksei Mikhailovich has not given anything to Nikon. In fact, he has usurped the privileges accorded to the Church by Christ, the only one with the power to bind and loose, he has enslaved the Church and he rules over it and over its property as an Antichrist who speaks through false, self-interested prophets such as the Metropolitan of Gaza. Priesthood is not the Tsar's to give, writes Nikon, and the Tsar has no authority to judge the clergy, or to convene synods and force the deposition of a Patriarch "by his own bishops".

Second, insists Nikon, the Tsar did not imitate Constantine's gestures of respect towards Pope Sylvester and towards the Church. Quoting extensively from the "Donation" attributed to the emperor, a text that included a depiction of the officium

36. William Palmer, The Patriarch and the Tsar I. The Replies..., p. xxxIIxxxIII, 189-258; Valerie A. Tumins, George Vernadsky (ed.), Patriarch Nikon..., p. $260-318$. 
stratoris, the Patriarch retorts that none of the deeds of Aleksei Mikhailovich could match those of Constantine the Great, or of any other Byzantine emperor. And neither is the Tsar a match for Vladimir, Great Prince and convertor to Christianity of Kievan Rus'.

Briefly narrating the history of the ecclesiastical hierarchy, ascribed to Christ, of the baptism of Rus', attributed to the initiative of Vladimir, of the creation of the Moscow Patriarchate, ascribed to the initiative of the ecumenical Patriarch Jeremiah II, and of the ordination of Philaret Romanov as Muscovite Patriarch, attributed to the initiative of Theophanes of Jerusalem, Nikon emphasizes that the priesthood has divine origins and is "in all respects more honourable than royalty". ${ }^{37}$

Then he directs his attention towards Ligaridis' answer. The Tsar can honour whomever he pleases, says Nikon, but only among his subjects and servants, not among the Bishops. To honour the Church is not an option; it is a duty. Ahasuerus did indeed order that Mordecai be vested in royal robes and paraded on a horse led by the rein by his chief minster; however, he did so because Mordecai had saved his life. The Tsar did not show his Patriarch the same respect as Constantine the Great had shown to Sylvester, and there is no record about Justinian acting as a groom to Agapetus.

However, "That the Hossoudar the Tsar leads by the bridle a horse on which the metropolitan of Kroutitz is set, since it so pleases him, he can do it. Or, if he likes, he can set any other thing or person upon a beast, and lead it about. That depends quite upon his own will. But the Lord God gave no indication of his pleasure or commandment to his disciples about this, as if he said, 'Do this in remembrance of me', as he did with the bread and wine..." 38

A Bishop is "an image of God", underlines the Patriarch, while the Tsar's kingdom is of this world, his power being given to him

37. William Palmer, The Patriarch and the Tsar I. The Replies..., p. 189-236; Valerie A. Tumins, G. Vernadsky (ed.), Patriarch Nikon..., p. 260-298. In this part of the Refutation, Nikon draws intensively on the 1653 Кормчая книга; see Natalia V. Vorob'eva, “«Кормчая» как источник «Возражения или Разорения» патриарха Никона" [The "Nomokanon" as Source of Patriarch Nikon's "Refutation or Demolishment"], Вестник Тамбовского университета - Гуманитарные науки [Tambov University Review - Human Sciences] 12 (2008), p. 279-284.

38. William Palmer, The Patriarch and the Tsar I. The Replies..., p. 240-241; Valerie A. Tumins, George Vernadsky (ed.), Patriarch Nikon..., p. 303. 
by God "through the blessing of the bishop". A Tsar, a horse, and a Metropolitan cannot automatically make a re-enactment of Christ's entry into Jerusalem. And the Tsar definitely cannot take away something he did not give.

"There are two swords of authority, that is, the spiritual and the secular", concludes Nikon. One must support the other in time of adversity. And while the holder of the spiritual sword can show interest in secular affairs, the holder of the secular sword cannot and should not interfere in Church business. Like the Sun and the Moon, the Patriarch and the Tsar have equal power, each in his realm. Their power emanates from God; nevertheless, in things that have to do with the salvation of the soul, "the supreme Bishop is higher than the Tsar". ${ }^{39}$

Obviously, things were not going in the direction desired by Aleksei Mikhailovich. The leaking of the correspondence between Streshnev and Ligaridis had extended the rift between him and Nikon. As for the answer of the Eastern Patriarchs, it did not bring the desired break-through. On the one hand, the Metropolitan Athanasios of Iconium claimed the subscriptions on the document containing the answers were false and that he was sent by his uncle, the Patriarch Dionysios of Constantinople, to negotiate peace between the two belligerent parties. On the other hand, Patriarch Nektarios of Jerusalem wrote personally to the Tsar asking him to forgive Nikon. ${ }^{40}$

Soon after, Metropolitan Athanasios admitted (possibly under duress) that he had lied. Still, doubts had been cast. As a consequence, a second mission was sent to the Eastern Patriarchs. This time, Meletios of Chios and Stephanos of Andros were asked to invite them to Moscow, so that they could solve in person the ill-fated "Nikon case". Yet only the Patriarchs of Alexandria and of Antioch accepted. Warned by his Constantinopolitan friends that the Ottomans would interpret it as a sign of hostility, Nektarios of Jerusalem declined the call. Dionysios of Constantinople, understandably scared - for in 1657, Parthenios III had been executed for "conspiring" with the Russians - met with the Tsar's

39. William Palmer, The Patriarch and the Tsar I. The Replies..., p. 237-258; Valerie A. Tumins, George Vernadsky (ed.), Patriarch Nikon..., p. 298-318.

40. William Palmer, The Patriarch and the Tsar III. History..., p. 349-356, 363-369. 
envoy in secret, "at the house of the most illustrious domina Roxandra" Mavrocordatos, daughter of the wealthy and influential Kyr Skarlatos and wife of an intrepid merchant of Chios, and also refused the invitation. ${ }^{41}$

Sent to Istanbul in 1665, the cellarer of the Muscovite Miracle (Chudov) monastery received a similar answer from Parthenios IV. Incurring capital punishment for corresponding with the Russians without permission from the Sultan, the ecumenical Patriarch had no intention whatsoever of going to Moscow. Seizing the opportunity, Nikon launched a series of severe accusations against Ligaridis. The former interpreter of the Metropolitan of Gaza, Hierodeacon Agathangelos Zani Rhodokanakis of Chios, now a confidant of the Patriarch, had informed him about the quite unorthodox past of his former employer. ${ }^{42}$

Boldly, Ligaridis declared that he was ready to defend himself in front of a council. Although many of the accusations were true, he felt he had nothing to fear: he had become too instrumental for the Tsar to abandon him.

And the council did exonerate him. Brought in chains before of the assembly, Agathangelos did not retract. Still, his testimony was judged slanderous. In fact, in February 1665, on Palm Sunday, "in emulation, one would say, and imitation of Constantine the Great", the Tsar had transparently expressed his position by offering Ligaridis "a handsome head-dress" and by ascribing him the role of St Peter in the re-enactment of the ensuing ceremony of the Washing of the feet. ${ }^{43}$ The Metropolitan of Gaza was right to assume, maliciously, that Nikon must have taken this as an insult. But the

41. Ibidem, p. 89.

42. For details on Hierodeacon Agathangelos Zani Rhodokanakis, see Vera G. Tchentsova, "Le premier voyage du patriarche d'Antioche Macaire III Ibn al-Za'īm à Moscou et dans les Pays roumains (1652-1659)", in Ioana Feodorov (ed.), Relations entre les peuples de l'Europe Orientale et les chrétiens arabes au XVII siècle. Macaire III Ibn al-Za'ìm et Paul d'Alep. Actes du I $^{e r}$ Colloque international le 16 septembre 2011, Bucarest, Bucharest: Editura Academiei Române 2012, p. 69-122; Eadem, "Первое путешествие Антиохийского патриарха Макария III Ибн аз-За“'има в Москву (16521659): контакты и конфликты" [The First Voyage of Patriarch Makāriyūs of Antioch to Moscow 1652-1659): Contacts and Conflicts], Вестник Православного Свято-Тихоновского гуманитарного ун-та - Филология [Review of St Tikhon's Orthodox Human Sciences University - Philology], 5 (35) (2013), p. 116-130].

43. William Palmer, The Patriarch and the Tsar III. History..., p. 99-100. 
truth was that the "case" was heading inexorably towards its end. In January 1666, the letters from Nikon to the Eastern Patriarchs and to the former Patriarch Parthenios of Constantinople were intercepted by the Tsar's men: the Moscow Patriarch was isolated. ${ }^{44}$ In November 1666, Paisios of Alexandria and Makāriyūs of Antioch arrived in Moscow. Immediately after, Nikon's trial began.

The result did not take anyone by surprise. In spite of Nikon's defence, the Russian and Greek prelates deposed him - the former Patriarch was declared a simple monk -, and condemned him to confinement in the remote Ferapontov monastery. ${ }^{45}$ What came however rather unexpectedly was the refusal of several Russian bishops to ratify Nikon's deposition, due to some passages asserting the absolute supremacy of the secular power. Yet their opposition was quickly discarded, and the ephemeral dissidents signed the decision. Soon afterwards, that is, in February 1667, Joasaph II was elected Patriarch of Moscow and of All Rus'.

\section{"A Fair Mirror of Human Life"}

The "humble Metropolitan Paisios of Gaza" felt the need to recall all these events in along Report ${ }^{46}$ In the dedication to the Tsar, his "vindicator and defender", he writes that his work is "a history from the beginning to the end of all that has been done

44. See Elke Matthes-Hohlfeld, Der Brief des Moskauer Patriarchen Nikon an Dionysios Patriarch Konstantinopel, Amsterdam: Aldolf M. Hakkert 1970. For an English translation, see William Palmer, The Patriarch and the Tsar III. History..., p. 381-400. See also Vera G. Tchentsova, "О писце греческой грамоты патриарха Никона" [The Scribe of Patriarch Nikon's Greek Letter], КЧ 11 (2013), p. 108-119.

45. According to the Report of Ligaridis, the Greek party consisted of seven metropolitans (Paisios [Ligaridis] of Gaza, Theodosios of "Varsavion" [that is, of "Serbia"], Gregorios of Niceea, Kosmas of Amasias, Athanasios of Iconium, Philotheos of Trebizond, Theophanes of Chios) and one archbishop (Ananias of Sinai); see William Palmer, The Patriarch and the Tsar III. History..., p. 169. The official account also mentions some "minor" prelates, such as the "hegoumenos" Dionysios of Iviron, the soon-to-be author of a massive History of Russia; see ibidem, p. 439-440. For details on some of the signatories, see Liudmila A. Timošina, "Греки и русские в Москве в 1665 г." [Greeks and Russians in Moscow in 1665], КЧ 3 (2005), p. 41-53.

46. For details, see Olga Alexandropoulou, "The History of Russia in Works by Greek Scholars of the Seventeenth-Century", Cyrillomethodianum 13-14 (1989-1990), p. 61-91. 
against Nikon, diversified with multitudes of canons and curious matters, adorned with grave questions and answers, and flowered over in profusion with patriarchal decisions and synodical suggestions". This "synodical book", he adds, this "tribute" to the all-mighty ruler, is straightforward and simple; its author holds to the truth, as did once Thucydides and Polybius, Dionysios of Halicarnassus and Plutarch. ${ }^{47}$

In fact, Ligaridis does hold fast to truth. It is only that it is his truth. ${ }^{48}$ First, he praises the Tsar as a God-chosen "saviour and helper of ruined Greece", by "un-rhetorically" playing with the words "Aleksei" - "A $\lambda \dot{\varepsilon} \xi 10 \varsigma$ " "Alexios" - "protection":

\section{`A $\rho \xi \varepsilon 1 \zeta \lambda \alpha 0 \tilde{v}$ \\ غ̇ं $\varepsilon v \theta \dot{\varepsilon} \rho \circ$ \\ $\xi \varepsilon v о \pi \rho \varepsilon \pi \tilde{\omega} \zeta$

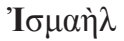 \\ ò $\lambda \varepsilon \dot{\varepsilon} \theta \rho \mathrm{v}$

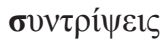

that is, "Thou shalt rule over the people freed [by thee] marvellously the Ishmaelite the destroyer you shall crush" ${ }^{49}$ Then, he "straightforwardly" draws a "physical portrait" of Nikon, "simply" depicting him as a monstrous being. ${ }^{50}$

Finally, he "truthfully" narrates the events that led to the fall of the "monster", underlining his own role as much as he can - for example, a chapter is dedicated to his own arrival in Moscow, another one depicts his fight against the "schismatics", while yet another one stresses his efforts to counter the "Russian innovators", whose appearance is blamed on Nikon ${ }^{51}$; not ever

47. William Palmer, The Patriarch and the Tsar III. History..., p. 15-21.

48. For a different version of the events, written by a "protégé and confidant" of Nikon, see Kevin M. Kain, Katia Levintova (ed.), From Peasant to Patriarch. Account of the Birth, Upbringing, and Life of His Holiness Nikon, Patriarch of Moscow and All Russia, Written by His Cleric Ioann Shusherin, Lanham-BoulderNew York-Toronto-Plymouth: Lexington Books 2007.

49. Ibidem, p. 19.

50. Ibidem, p. 21-27.

51. Ibidem, p. 50-57, 106-110. Actually, Ligaridis did engage in several polemics during his stay in Moscow. See Nikolai I. Subbotin (ed.), Mamepiaлbl... IX/1; see also Georg Michels, "The Place of Nikita Konstantinovič Dobrynin in the History of Early Old Belief", Revue des Études Slaves 69 (1997), 1, p. 21-31. 
listening to the other side - for example, he reproduces his reply to Nikon's letter, but does not say what Nikon actually wrote; bending the facts to fit his purpose - for example, Dionysios of Constantinople did not appoint him "interpreter" of the official patriarchal answers, nor "the most confidential mouthpiece of all the synod"; and the list could easily go on. ${ }^{52}$

Ligaridis' intentions are however transparent. He wants to show that Nikon's deposition was necessary, just and legal, and that the Tsar - a true heir to Constantine the Great, "the phoenix of Christian emperors and kings" ${ }^{53}$ - was entirely entitled to act as he did. And of course, he wants his role in the "affair" to be acknowledged.

The Report is divided into three parts. The first one begins with the Grand Prince of Muscovy Ivan IV assuming the title of Tsar, with the creation of the Moscow Patriarchate, and with a presentation of the privileges of each Patriarchal See; it continues with Nikon being elected Patriarch, with his "abdication", and with an account of the failed efforts to depose him; it vividly depicts the arrival of Ligaridis in Moscow, his involvement in the "case", and the efforts made in order to engage the Eastern Patriarchs in the conflict; it ends with Paisios of Alexandria and Makāriyūs of Antioch entering Moscow. The second part of the Report presents extensively the works and the decisions of the synod that condemned Nikon. The last part centres on the election of Joasaph II as Patriarch.

In fact, Ligaridis narrates how the Tsar, with his own "humble" help, solved a severe crisis generated by the "unworthy" Nikon. The Report starts with Nikon's nefarious self-imposed exile, and it ends with the consecration of the Holy Myron by a new legitimate Patriarch. ${ }^{54}$ It starts with the "widowhood" of the Church, and it

52. William Palmer, The Patriarch and the Tsar III. History..., p. 57-69, 89, 108-110.

53. Ibidem, p. 136.

54. On the importance and the significance of this ritual, see Louis Petit, "Du pouvoir de consacrer le Saint Chrême", Échos d'Orient 3 (1899), 1, p. 1-7; Idem, "Composition et consécration du Saint Chrême", ibidem 3 (1900), 3, p. 129-142; Ioan Dură, "La consécration du Saint Chrême dans l'Eglise Orthodoxe Roumaine entre le XVI et le XIX ${ }^{\mathrm{e}}$ siècle", Ephemerides Theologica Lovanienses 62 (1986), p. 283-307; Sebastian P. Brock, "Jacob of Edessa's Discourse on the Myron", Oriens Christianus 63 (1979), p. 20-36; Miguel Arranz, "Les sacrements de l'ancien Euchologe constantinopolitain 10. La consécration du Saint Myron," Orientalia Christiana Periodica 55 (1989), p. 317-338. 
ends with a "spiritual marriage". It starts with a catastrophe, and it ends with the restoration of order.

In this scenario, the Palm Sunday ritual of 1667 plays a minor yet important part. First of all, it underlines the fact that Nikon's successor, Joasaph II, was not Nikon. Indeed, as his Report reaches its end, Ligaridis emphasizes that the new Patriarch, voted "publicly and openly" by all the Russian ecclesiastics, "small and great", has nothing in common with the fallen Lucifer-turnednight-fox deposed old Patriarch. He stresses that Joasaph's election, endorsed by the Tsar - "new Constantine", "new Theodosius", "most excellent Justinian", "defender", "valiant champion" and "helper" of the Church -, brought peace and healed all divisions. He goes on to emphasize that the Empire and the Episcopate are two great and equal lights, and that Russian ecclesiastical affairs are administered according to the Eastern pattern. ${ }^{55}$

The celebration of Palm Sunday according to this Oriental pattern and not to the pattern so carefully reconstructed by Nikon becomes thus another sign of restored normality. Its description also allows Ligaridis to launch another attack against the former Patriarch, accused of pride: "But here do thou, $\mathrm{O}$ reader, note with me for a moment the arrogance of Nikon, who made the example of Christ to consist not in washing the feet of the disciples, but in sitting on the colt with $\beta$ ói $\alpha$ and boughs..." ${ }^{56}$ Implicitly, it provides Ligaridis with another opportunity to accentuate the Tsar's importance: according to the Report, Palm Sunday's officium stratoris is about the Tsar and his Christly-inspired humility towards God and the Church, and not about the diabolically-minded egotism of a Patriarch.

\section{Conclusions}

A similar interpretation was given to the ritual by the Wallachian prince Mihnea / Michael III Radu, in 1658. According to Būluṣ of Aleppo, on Palm Sunday of that year, the prince chose to imitate the Muscovite tsar. Well dressed, on foot, flanked by his courtiers, preceded by his equipped horses, holding by the bridal a mule upon

55. Ibidem, p. 273-279, 284-295.

56. Ibidem, p. 267-271, 273-279, 284-295, 306. 
which the country's metropolitan was seated, and followed by the main boyars, who were also on foot and leading horses, the prince encircled the town of Bucharest, as he had provisionally set up his residence in a monastery devoted to the Holy Trinity situated "on the outskirts of the city, high on a hill".

"Then they told us about this new prince that on Palm Sunday he [ordered] that the Moscow rites be performed precisely, with much dedication and care, because he was very pious, humble, and devoted...

As to the day of the Palm celebrations, he thought of what the [Russian] emperor did in Moscow and he did exactly the same, especially since no other prince before him had ever acted this way. Hence he dressed the Christian soldiers in their most beautiful coats and came out with great ceremony. The Metropolitan of the country was riding a mule, in full canonical dress, holding the Gospels and the cross in his right hand, and the prince himself held the bridle. Left and right the house footmen advanced, while the princely horses trotted in front of them. He himself walked, accompanied by all the court dignitaries, each of them holding the bridle of his horse. Heavy rain started to pour and thick mud started to form. Nevertheless, they went around the whole city of Bucharest and returned to the monastery, where they completed the Mass. ${ }^{.57}$

What triggered this spectacular imitation of the Muscovite Palm Sunday ritual? Named and imposed by the Ottomans, with Tatar support, the new Wallachian prince of obscure Greek origins had entered a devastated country with a devastated capital, with no local support, and had to deal with an intricate international (political) conjuncture. In short, he was in a deep need of legitimacy. In order to strengthen his position, someone familiar with the Russian customs or with Adam Olearius' 1636 depiction of the Muscovite Palm Sunday celebrations, printed in 1647 and 1656 in German and soon translated into Dutch, French and Italian, suggested a "Muscovite" approach: the prince had to show his respect towards the Church; his display of humility would reveal the divinely sanctioned character of his newly-acquired and fragile power. ${ }^{58}$

57. Ioana Feodorov, "Mihnea III Radu...., p. 296-297.

58. For details, see Radu G. Păun, "Si Deus nobiscum, quis contra nos? Mihnea III: note de teologie politică" [Si Deus nobiscum, quis contra nos? Mihnea III: Notes of Political Theology], in Ovidiu Cristea, Gheorghe Lazăr (ed.), Naţional şi universal în istoria românilor. Studii oferite Prof. Dr. Șerban Papacostea cu ocazia implinirii a 70 de ani [National and Universal in the History of the Romanians. Studies Offered to Prof. Dr. Șerban Papacostea on the Occasion of his $70^{\text {th }}$ Anniversary], Bucharest: Editura Enciclopedică 1998, p. 69-99; Idem, "Pouvoir, Croisade et Jugement 
Who was this connoisseur of Russian ways? Būluṣ of Aleppo does not provide any clues. However, a highly plausible candidate is our Paisios Ligaridis: in 1658, the Metropolitan of Gaza was "confessore, predicatore e teologo" of prince Mihnea / Michael III Radu ${ }^{59}$ in 1659 , he seems to be involved in the assembly of a local council in the capital of Wallachia. ${ }^{60}$ [III, 1-2] The bold idea of imitating the Tsar highly resembles a plan Ligaridis would have coined or at least approved of.

Irrespective of the identity of the mysterious adviser (or advisers?), the "arch-manipulator" Metropolitan of Gaza did advocate while in Moscow in 1662-1667 the reading in a proimperial key of the equerry service performed by the Tsar on Palm Sunday. And the way he did it had consequences. In 1678, the Palm Sunday ritual was again performed according to Nikon's indications. ${ }^{61}$ This would suggest a limited effect of the 1667 damnatio memorice. Yet in 1694, Peter the Great did not lead the Patriarch's calf or horse by the reins; soon, ignored by the sovereign, Palm Sunday ceased to be a Court ritual, and, together with the Epiphany ritual, became "a non-political folk ceremony" ${ }^{62}$ Paul Bushkovitch links Peter's growing lack of interest in the two festivals with the Tsar's growing interest in the (in)famous Most-Comical All-Drunken Council, that is, in a new manner of

Dernier au XVII ${ }^{\mathrm{e}}$ siècle", in Ivan Biliarsky (ed.), Ius et ritus. Rechtshistorische Abhandlungen über Ritus, Macht und Recht, Sofia: Iztok-Zapad 2006, p. 213-281; Ovidiu Olar, "Mihnea al III-lea Radu şi Roma (1658-1660)" [Mihnea III Radu and Rome (1658-1660)], in Ovidiu Cristea, Petronel Zahariuc, Gheorghe Lazăr (ed.), Viam inveniam aut faciam. In honorem Ştefan Andreescu, Iaşi: Editura Universităţii "Alexandru Ioan Cuza" 2012, p. 439-450.

59. Émile Legrand, Bibliographie hellénique..., p. 18; Andreas Septyckyi (ed.), Monumenta..., p. 299 (no 168).

60. Ştefan Andreescu, "Moştenirea politică a lui Mihai Viteazul la mijlocul veacului XVII" [The Political Heritage of Michael the Brave at the Middle of 17 $7^{\text {th }}$ Century], AIIAI 23 (1986), 1, p. 143-161 [= Idem, Restitutio Dacia II. Relațiile politice dintre Ţara Românească, Moldova şi Transilvania în răstimpul 1601-1659 (Restitutio DaciæII. The Political Relationship between Wallachia, Moldavia and Transylvania between 1601-1659), Bucharest: Albatros 1989, p. 225-282].

61. Nikolai I. Novikov (ed.), Древняя российская вивлиофика [Ancient Russian Library] 11 (1789) [Moscow: Типография компании типографической], p. 64-67.

62. Paul Bushkovitch, "The Epiphany Ceremony of the Russian Court in the Sixteenth and Seventeenth Centuries", Russian Review 49 (1990), 1, p. 15-17. 
conceiving and achieving sacral authority. ${ }^{63}$ While I am convinced by this hypothesis, I would argue that Ligaridis might also have had his share in the fading of Palm Sunday as a "royal" ritual.

Of course, Peter the Great did not know the Report, or Account, of the partial council which took place in illustrious Moscow against the erstwhile Patriarch Nikon. Ligaridis' work was never published, and it does not seem to have ever been translated or copied. However, as Maureen Perrie has shown, the Metropolitan of Gaza contributed a lot to the decline of the idea of Muscovy as the "New Jerusalem" and of Russia as the "New Israel". ${ }^{64}$

Indeed, in July 1663, when sent to Nikon's monastery of the Resurrection to enquire whether the Patriarch had cursed the Tsar, Ligaridis states that the monastery was "falsely called... 'New Jerusalem"', and associates Nikon with the Antichrist. The Report recollects the meeting between the Patriarch and the Metropolitan of Gaza, and reissues the severe allegations. In addition, towards the end, Ligaridis praises the "all-holy city of Jerusalem, my country, my soul, and my metropole", and slurs Nikon for believing that the "life-giving Sepulchre", Bethlehem, and Golgotha are "everywhere". "At Jerusalem there are the originals", he says, "but elsewhere only copies or symbols". ${ }^{65}$

Palm Sunday was the re-enactment of Christ's entry into Jerusalem, and Nikon had tried to make it more historically accurate precisely because it was an important part of the Muscovite "New Jerusalem" / "New Israel" project. The breaking up of the partnership between Tsar Aleksei Mikhailovich and Patriarch Nikon, and especially the fading of the "New Jerusalem" / "New Israel" theme from mainstream political discourse, undermined the efficacy of the Palm Sunday ritual, too. Edward Muir has drawn attention to the importance of rituals in the governing of Early Modern Europe ${ }^{66}$ A symbolically "impoverished" ritual was less

63. Ibidem. For the carnivalesque council, see Ernest A.Zitser, The Transfigured Kingdom. Sacred Parody and Charismatic Authority at the Court of Peter the Great, Ithaca: Cornell University Press 2004 [see also Aleksandr Lavrov's review in Cahiers du Monde Russe 46 (2005), 4, p. 862-864].

64. Maureen Perrie, "Moscow in 1666...".

65. William Palmer, The Patriarch and the Tsar III. History..., p. 76-82, 309-310.

66. Edward Muir, Ritual in Early Modern Europe, Illinois: Northwestern University $2005^{2}$. 
useful in terms of governance and, as a consequence, less attractive for a ruler, especially for one like Peter the Great.

As Philippe Buc has warned, there are dangers connected with rituals.$^{67}$ In the case under study here, the Palm Sunday ritual was subject to manipulation by both Nikon and his enemies. To complicate things even further, Ligaridis' description of the 1667 ceremony is "highly crafted", and so is Nikon's version. Yet the analysis of the texts in dialogue with one another and in their contexts allows us to reconstruct the different and multilayered interpretations of the same ritual and the rationale behind the struggle to impose a sole interpretation of this ritual. All contenders were aware of the fragility of their position. Both were however determined to impose their point of view, the Patriarch insisting on the pre-eminence of the Church, while the Metropolitan advocated the pre-eminence of the State. The "publics" they addressed were different, as Nikon was targeting mainly a Muscovite and a Russian-speaking audience, while Ligaridis wrote mostly for the Tsar and for an "Eastern", Greek-speaking audience. ${ }^{68}$ Their struggle undermined the "political" load of the ritual that they were trying to control; it also decisively shaped the Muscovite political culture of the time.

ovidiuolar@gmail.com

67. Philippe Buc, The Dangers of Ritual. Between Early Medieval Texts and Social Scientific Theory, Princeton: Princeton University Press 2002; one should not forget, however, that this book is "dangerous" - see Geoffrey Koziol, "The Dangers of Polemic: Is Ritual still an Interesting Topic of Historical Study?", Early Medieval Europe 11 (2004), 4, p. 367-388.

68. For the echo of Nikon's Refutation, see Svetlana K. Sevastyanova, "Новонай-денное сочинение о патриархе Никоне" [The Newly Found Composition about Patriarch Nikon], in Культура, история и литература Русского мира: общенациональный и региональный аспекты [The Culture, History and Literature of the Russian World: National and Regional Aspects], Barnaul: Изд-во Алтайского гос. технического ун-та 2014, p. 335-380. The impact of Ligaridis' Report remains to be studied. 


\section{ABBREVIATIONS}

AAR - MSI - Analele Academiei Române - Memoriile Secţiunii Istorice

AIIAI - Anuarul Institutului de Istorie şi Arheologie "A. D. Xenopol” Iaşi

BAR - Biblioteca Academiei Române (București) / Library of the Romanian Academy (Bucharest)

ГИМ - Государственный исторический музей (Москва) / State Historical Museum (Moscow)

КЧ - Каптеревские чтения

RESEE - Revues des Études Sud-Est Européennes

VV - Византийский Временник

ТОДРЛ - Труды Отдела древнерусской литературы

ЧОИДР - Чтения в обществе истории и древностей российских 


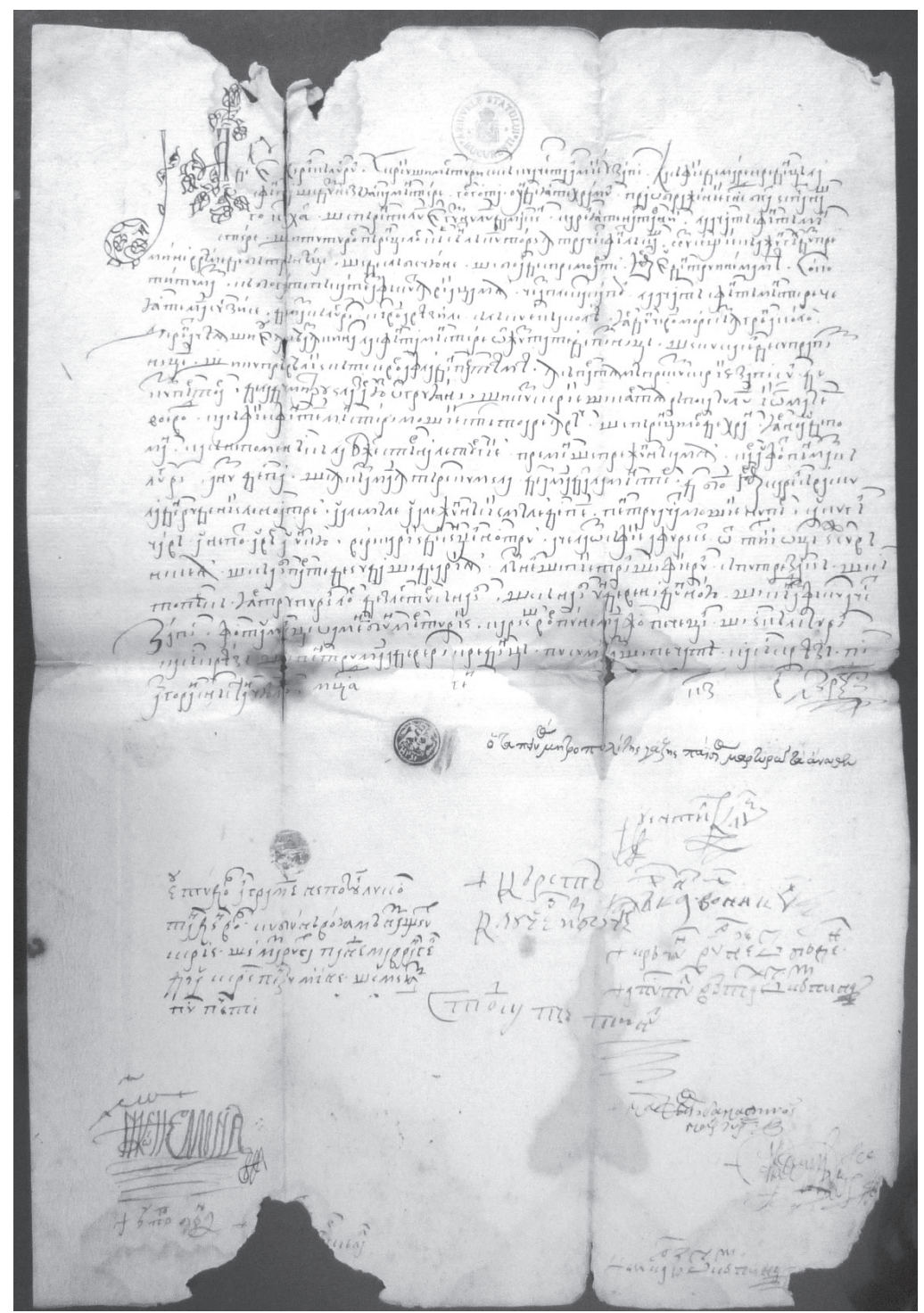

Fig. 1. January 27, 1659. Târgoviște.

Monk Chiril offers Golgota monastery half a cellar, the buildings above and the shops from the neighbourhood. Among the testimonies is that of the "humble" metropolitan of Gaza Paisios (Ligaridis) [DANIC, M-rea Golgota, V/14]. Courtesy of DANIC. 


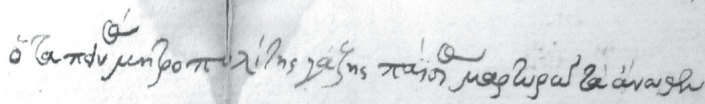

Fig. 2. January 27, 1659. Târgoviște.

Monk Chiril offers Golgota monastery half a cellar, the buildings above and the shops from the neighbourhood.

Detail - signature of Metropolitan Paisios of Gaza

[DANIC, M-rea Golgota, V/14]. Courtesy of DANIC. 